\title{
A Study of Effectiveness of Enhancing College Students' English Proficiency through English Salon_-Taking AlB English Salon as an Example
}

\author{
Fen WANG ${ }^{1, a,{ }^{,}, \text {Kai-Yan FENG }}{ }^{2, b}$ \\ 1The library of Guangdong AIB Polytechnic College, Guangzhou, Guangdong, China \\ 2 Computer Science Department of Guangdong AIB Polytechnic College, Guangzhou, Guangdong, \\ China \\ *a wangfen209@126.com, baddland@126.com
}

Keywords: English Salon, English Listening and Speaking, College Students

\begin{abstract}
In 2011 English salon was established in Guangdong AIB Polytechnic College. A survey response (80.74\%) from 302 of 374 students who took part in English salon was conducted to analyze the merits and problems of English salon. The results were as follows: (1) English salon is effective in improving college students' English proficiency especially English listening and speaking; (2) English salon helps college students develop other ability and skills such as problem solving skills, leadership skills and management skills. Even though there exist some potential problems and disadvantages, measures will be taken to improve English salon in order to benefit more students.
\end{abstract}

\section{Introduction}

As is known to all, English listening and speaking are very important in learning English. As the second class of English training, English salon refers to a style which allows students to develop a more comprehensive and in-depth language skills level ${ }^{[1]}$. English salon is a way of Communicative Language Teaching (CLT). The goal of CLT is to develop students' communicative competences which include the knowledge about language and the knowledge about how to use language appropriately in real communication ${ }^{[2]}$. English salon has created the communication environment of linguistic comprehensive application for students which is freer, easier and closer to life so that students can put their knowledge into practice. Through constant practice, students can improve English listening and speaking as well as other skills. In 2011 English salon was established in Guangdong AIB Polytechnic College and since then it has successfully organized 168 English Salon with a total number of attendees exceeding 15000 people. AIB English salon recruits more than 100 volunteers every year to help run the salon, which is divided into six groups - host department, public relations department, logistics department, technical department, photography department and propaganda department. In 2017 AIB English salon became a students' English training base which serves to provide a new space for the students to have a basic level of English proficiency to meet professional requirement. Taking AIB English Salon as an example, the paper is to explore the effectiveness of enhancing college students' English proficiency through English salon.

\section{Methodology}

\section{Aim of the Research}

The primary objective of the research was to determine whether English salon is effective in improving college students' English proficiency especially English listening and speaking. The secondary objective was to determine whether English salon helps college students develop other ability and skills such as problem solving skills, leadership skills and management skills. 


\section{Method of the Research}

Given the research objective, which is conceptually descriptive, we choose the method of questionnaire, which we considered to be the most appropriate for this situation. The questionnaire included mainly dichotomous questions, semi-open questions and multiple-choice questions ${ }^{[3]}$. A total of 400 questionnaires were distributed, among which 388 were recovered, and 374 valid questionnaires were collected - the recovery rate was $97 \%$ and the effective rate was $96.39 \%$. Of the 374 valid questionnaires, 302 students participated in the English salon activity accounting for $80.74 \%$ of the total number of participants, and 72 students never participated in the activity accounting for $19.25 \%$ of the total number of participants.

\section{The Research Sample}

Empirical research was conducted in a total of 302 students who took part in AIB English Salon from 2012 to 2016, including some graduates, 138 English major students and 164 non-English major students.

\section{Research Results}

As the table1 shows, $67.22 \%$ of the students believe that English salon helps them learn English, $27.48 \%$ of the students are not sure whether English salon is helpful, only $5.3 \%$ of the students think English salon will not help them to learn English. It shows English salon is accepted by most of students.

Table 1 Do you think English Salon is helpful to learning English?

\begin{tabular}{|c|c|}
\hline Item & Percentage \\
\hline Not helpful at all & $1 \%$ \\
\hline Not helpful & $4.3 \%$ \\
\hline Not sure & $27.48 \%$ \\
\hline Helpful & $40.40 \%$ \\
\hline Helpful very much & $26.82 \%$ \\
\hline
\end{tabular}

Table 2 shows that $54 \%$ of the students use English at the work, part-time job, or internship, and $46 \%$ of the students do not use English in those circumstances. In the age of globalization, English proficiency has become the competitiveness of employment. It is necessary for students to practice spoken and listening English.

Table 2 Do you use English at work, part-time job, or internship?

\begin{tabular}{|c|c|}
\hline Item & Percentage \\
\hline Yes & $54 \%$ \\
\hline No & $46 \%$ \\
\hline
\end{tabular}

English salon was usually held 12-14 times one semester. As table 3 shows, 57.95\% of the students participate in more than 6 times one semester, and $12.25 \%$ of the students participate in 12-14 times. It shows that the frequency of students who take part in English salon is high - English salon is popular. 
Table 3 How many times a semester have participated in an English Salon?

\begin{tabular}{|c|c|}
\hline Item & Percentage \\
\hline 1-3 times & $20.20 \%$ \\
\hline 3-6 times & $21.85 \%$ \\
\hline 6-9 times & $27.82 \%$ \\
\hline 9-12 times & $17.88 \%$ \\
\hline 12-14 times & $12.25 \%$ \\
\hline
\end{tabular}

The purpose of college students who participate in English salon is more diverse, not only for training English proficiency but also for expanding the horizon and communication. The students do not give priority to professional development and improving exam score and pay more attention to their own actual need. Making friends and exercising listening become one of the main reasons for students to attend English salon (79\% and 74\% respectively), and $62 \%$ of the students want to learn basic knowledge which ranks third. Entertainment ranks fourth. Cross-culture knowledge and Academic/lessons ranks fifth. Professional development, English competition and improving exam score accounts for $39.72 \%, 19 \%$ and $18 \%$ ranking sixth, seventh and eighth as the figure 1 shows.

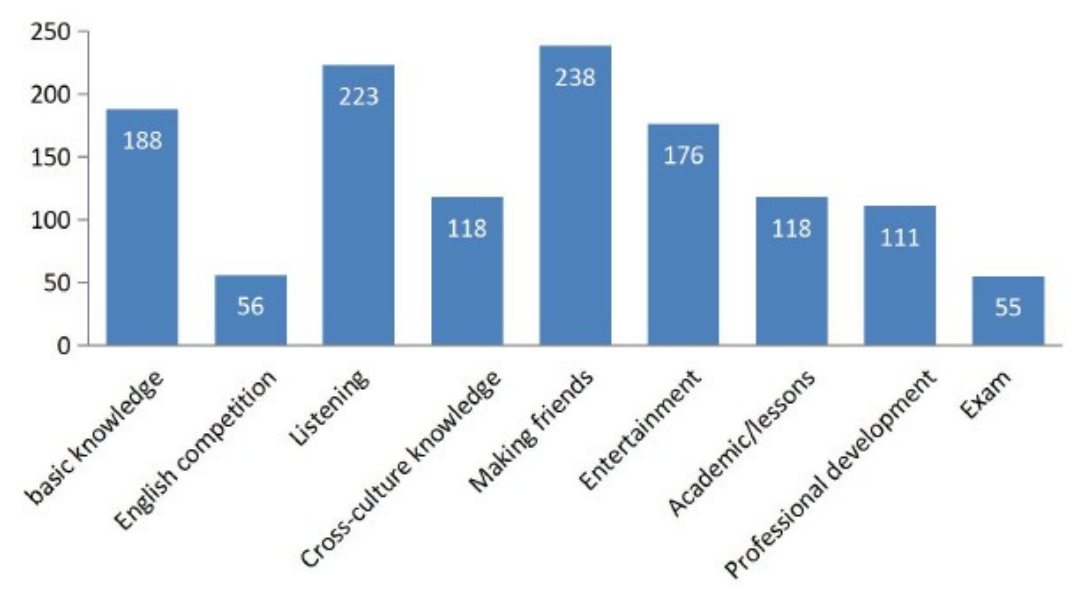

Figure. 1 why do you participate in the English Salon? (Multiple Choice)

Figure 2 shows the situation of the students using English during an English salon session. 3\% of the students use only English. 28\% of the students use mostly English and some Chinese. 48\% of the students use both Chinese and English. 19\% of the students use mostly Chinese and some English. 1\% of the students use Chinese only.

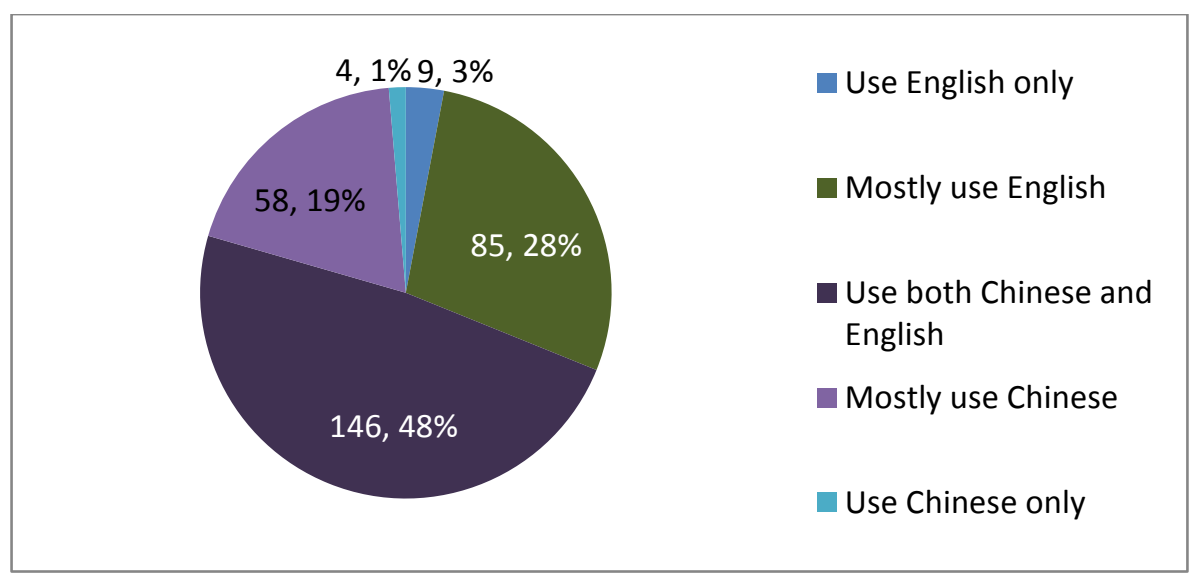

Figure. 2 which best describes your use of English during an English Salon session? 
As shown in table 4, more than half of the students think English salon helps on their pronunciation, fluency and vocabulary in varying degrees $(61.27 \%, 52.66 \%$ and $50.99 \%$, respectively). Only $32.45 \%$ and $21.55 \%$ of the students think that English salon is helpful to their sentence structure and grammar at different levels. It is obvious English salon improves the students' oral English. However, it is limited to improve students' grammar.

Table 4 how much did English Salon help you learn Oral English?

\begin{tabular}{|l|c|c|c|c|c|}
\hline \multicolumn{1}{|c|}{ item } & \multicolumn{5}{|c|}{ percentage } \\
\hline \multicolumn{1}{|c|}{$\begin{array}{c}\text { Not helpful at } \\
\text { all }\end{array}$} & Not helpful & Not sure & helpful & $\begin{array}{c}\text { Helpful very } \\
\text { much }\end{array}$ \\
\hline Grammar & $2.32 \%$ & $10.26 \%$ & $34.77 \%$ & $33.78 \%$ & $18.88 \%$ \\
\hline Vocabulary & $7.28 \%$ & $29.12 \%$ & $42.05 \%$ & $16.56 \%$ & $4.99 \%$ \\
\hline Pronunciation & $1.32 \%$ & $11.92 \%$ & $35.76 \%$ & $33.44 \%$ & $17.55 \%$ \\
\hline Sentence structure & $1.98 \%$ & $10.26 \%$ & $26.49 \%$ & $36.44 \%$ & $24.83 \%$ \\
\hline
\end{tabular}

Passing all kinds of English test is still one of the main reasons for students to learn English. English salon helps students to learn knowledge and the skill of the exams. Figure 3 showed that $83.44 \%$ and $44.37 \%$ of the students think that to attend English salon is helpful to CET4 and CET6. $40.40 \%$ of the students think English salon helps them pass A\&B exam. $29.47 \%$ and $21.52 \%$ of the students think English salon helps them pass their professional license exam and advanced college entrance exam. Only $6.29 \%$ of the students think it is helpful to ITELS \& TOEFL test.

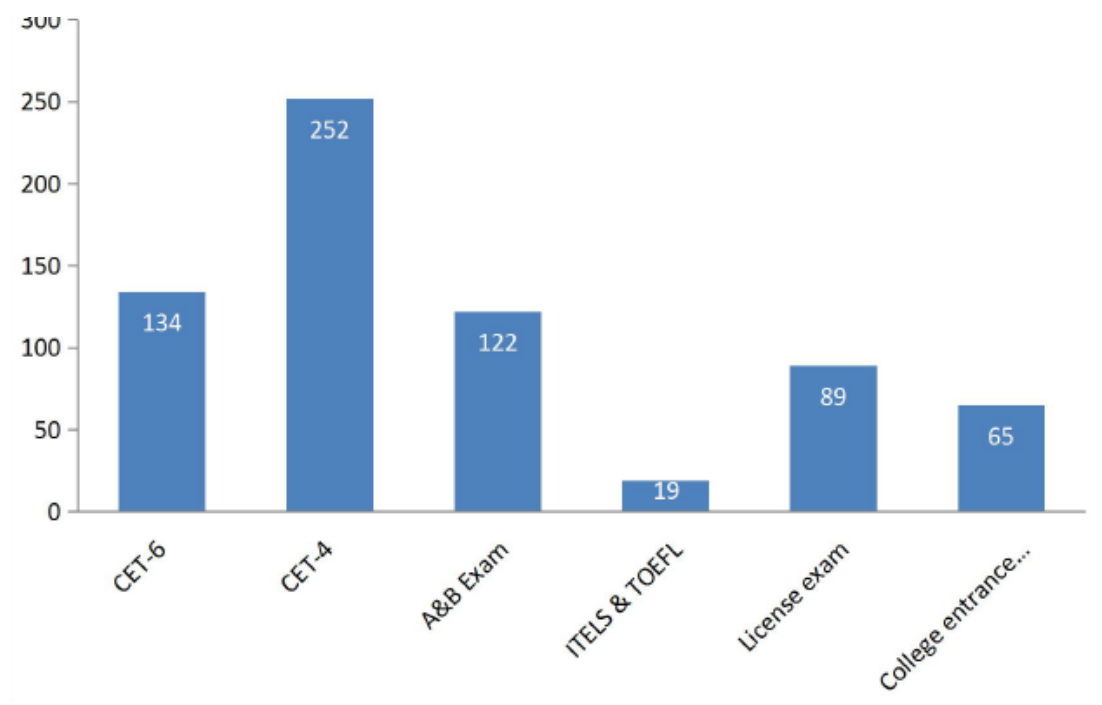

Figure. 3 what type of exams does English Salon help you? (Multiple Choice)

It is obvious that English salon improves the students' listening and speaking skills, and has also developed their comprehensive quality (especially for the English salon staffs). Table 5 shows that more than half of the students think that English salon is helpful at different levels to their public speaking skills and listening skills, accounting for $61.26 \%$ and $57.94 \%$ respectively. $43.74 \%, 43.08 \%$ and $41.40 \%$ of the students believed that English salon was very helpful and helpful to their leadership, management and problem-solving skills. 
Table 5 How helpful was English Salon to your skill development?

\begin{tabular}{|c|c|c|c|c|c|}
\hline item & \multicolumn{5}{|c|}{ percentage } \\
\hline & $\begin{array}{c}\text { Not helpful } \\
\text { at all }\end{array}$ & $\begin{array}{c}\text { Not } \\
\text { helpful }\end{array}$ & $\begin{array}{c}\text { Not } \\
\text { sure }\end{array}$ & helpful & $\begin{array}{c}\text { Helpful very } \\
\text { much }\end{array}$ \\
\hline Listening skill & $1.98 \%$ & $7.95 \%$ & $32.12 \%$ & $36.75 \%$ & $21.19 \%$ \\
\hline Public speaking skill & $3.64 \%$ & $11.59 \%$ & $23.51 \%$ & $34.44 \%$ & $26.82 \%$ \\
\hline Problem solving skills & $4.30 \%$ & $16.22 \%$ & $38.08 \%$ & $28.15 \%$ & $13.25 \%$ \\
\hline Leadership skills & $5.6 \%$ & $16.89 \%$ & $33.77 \%$ & $28.48 \%$ & $15.26 \%$ \\
\hline Management skills & $5.6 \%$ & $15.23 \%$ & $36.09 \%$ & $30.5 \%$ & $12.58 \%$ \\
\hline
\end{tabular}

A total of 251 students responded to "Does the English salon have any problems or weakness?". $26.29 \%$ of the students think that English salon needs more advertisement. $25.89 \%$ of the students think that English salon management system is not perfect and the staffs are short of communication and cohesion. $9.16 \%$ of students think that audience participation is not high because of low English level and lack of self-confidence. As for activities, $20.72 \%$ of students think that the activity forms are not abundant and reasonable so that students easily lose their interest in involving in it. $8.76 \%$ of the students believe that the topic is not new and the content richness needs to be improved. $9.16 \%$ of the students believe that the host quality should be improved, especially in spoken English. 9.16\% of students think the space is limited. Furthermore, a total of 258 students responded to "Do you have any suggestions or comments to help us improve?" The results are as follows: intensifying propaganda, building better management system, strengthening teamwork and communication among staffs, varying in the form of activity and choosing diversified topics, cooperating with different partner as the table 6 shown.

Table6 Problems \& Suggestions

\begin{tabular}{|l|c|}
\hline \multicolumn{1}{|c|}{ Problems } & Suggestions \\
\hline 1, Lack of Advertisement for & 1, Intensify propaganda \\
English salon & 2, Perfect management system \\
2,Incomplete management system & 3, Strengthen teamwork and \\
3, Lack of communication and & $\begin{array}{l}\text { communication } \\
\text { cohesion among staffs }\end{array}$ \\
$\begin{array}{l}\text { 4, The diverse and abundant form of } \\
\text { 5, Lack of original themes and host } \\
\text { quality, monotonous forms and } \\
\text { limited space }\end{array}$ & 5,Diversified topics \\
\end{tabular}

\section{Conclusion}

In summary, as a supplementary to teaching program and Extra-curriculum Activity (ECA), English salon has a good and effective influence on students' English learning ${ }^{[4]}$. It cultivates and stimulates students' enthusiasm and confidence in learning English, and promotes the college students' comprehensive abilities of language usage especially English listening and speaking. On the other hand, English salon helps college students develop other ability and skills such as problem solving skills, leadership skills and management skill. Even though there exist some potential problems and disadvantages, measures will be taken to improve English salon in order to benefit more students. Therefore, English salon should be utilized more aggressively to language education especially for college students 


\section{References}

[1]Wang Fen, Fernando Graciano. Use of English Corner and English Salon as a Language Learning Program at Polytechnic College Based on BPM[M], Advances in Education Research, 2012(11): pp150-154.

[2]Lu Shaoping. School-Based Curriculum Development-Oral English Salon Teaching Case [J], Views, 2009(06): pp148-149.

[3]L.Cohen,L.Manion and K.Morrison. Research methods in education. $5^{\text {th }}$ ed.London: RoutledgeFalmer, 2005.

[4]Liang Dan. Extra-curriculum Activity Groups in English Learning [J], Overseas English, 2012(12): pp21-25. 